\title{
Evaluasi Ruang Kerja Bagian Rekam Medis Rawat Inap Berdasarkan Aspek Tata Ruang Kantor di Rumah Sakit Delta Surya Sidoarjo
}

\author{
Yasida Bella Asri' ${ }^{1}$, Bambang Nudji ${ }^{2}$, Muhadi $^{3}$, Yustinah Rumiati ${ }^{4}$ \\ ${ }^{123}$ STIKES Yayasan Rumah Sakit Dr.Soetomo Surabaya \\ ${ }^{4}$ Rumah Sakit Delta Surya Sidoarjo \\ Email: yasidabellaasri@gmail.com ${ }^{1}$, bbnudji@gmail.com², muhadi@stikes-yrsds.ac.id ${ }^{3}$, \\ yustina.rumiati@gmail.com ${ }^{4}$
}

\begin{abstract}
Delta Surya Sidoarjo Hospital is a type C hospital, with a medical records room area of $33 \mathrm{~m} 2$, which has facilities including: tables, chairs, wardrobes and others. Where the medical records workspace is often found piles of inpatient Medical Record Files, on the table and on the floor. With a limited area, the Medical Record workspace looks more narrow, because many piles of inpatient medical record files are not yet processed. With such conditions, the access road for Medical Recorders is increasingly less flexible. In addition, the security of medical record files is not guaranteed and is very vulnerable to loss of medical record files. Based on the description of the problem above, it becomes the basis for researchers to conduct research on the evaluation of medical records workspace based on aspects of office layout at Delta Surya Hospital Sidoarjo. With a high enough workload can result in work fatigue and will also result in health problems. To minimize these adverse effects, it takes real efforts from the hospital. One effort that can be done is to pay more attention to work environment factors. This study aims to redesign the medical recorder workspace based on aspects of office layout at Delta Surya Sidoarjo Hospital. This type of research uses quantitative descriptive research, the subject of this study is the medical recorder workspace at the Delta Surya Hospital Sidoarjo. The instrument of this study used observation sheets and questionnaire sheets. In this study the observation sheet is used to find out the object of research directly, so that researchers easily understand the implementation process in the field. Data presented later based on field surveys will be compared with theory.
\end{abstract}

Keywords: Medical records, hospitalization, office layout

\begin{abstract}
Abstrak
Rumah Sakit Delta Surya Sidoarjo merupakan rumah sakit tipe C, dengan luas ruang rekam medis adalah 33 $\mathrm{m} 2$, yang memiliki fasilitas antara lain: meja, kursi, almari dan lain-lain. Dimana ruang kerja rekam medisnya banyak ditemukan tumpukan Berkas Rekam Medis rawat inap, di atas meja dan di atas lantai. Dengan luas yang terbatas, ruang kerja Rekam Medis terlihat lebih sempit, karena banyak tumpukan berkas rekam medis rawat inap yang belum diolah. Dengan kondisi seperti itu, akses jalan untuk Perekam Medis semakin tidak leluasa. Di samping itu keamanan berkas rekam medis tidak terjamin dan sangat rawan terjadi kehilangan berkas rekam medis. Berdasarkan uraian permasalahan di atas, menjadi dasar pertimbangan peneliti untuk melakukan penelitian tentang evaluasi ruang kerja rekam medis berdasarkan aspek tata ruang kantor di Rumah Sakit Delta Surya Sidoarjo. Dengan beban kerja yang cukup tinggi dapat mengakibatkan kelelahan kerja dan akan berakibat pula pada gangguan kesehatan. Untuk meminimalisir dampak buruk tersebut, diperlukan upaya-upaya yang nyata dari rumah sakit. Salah satu upaya yang dapat dilakukan adalah dengan lebih memperhatikan faktor lingkungan kerja. Penelitian ini bertujuan untuk merancang ulang ruang kerja perekam medis berdasarkan aspek tata ruang kantor di Rumah Sakit Delta Surya Sidoarjo. Jenis penelitian ini menggunakan penelitian deskriptif kuantitatif, subjek dari penelitian ini adalah ruang kerja perekam medis di Rumah Sakit Delta Surya Sidoarjo. Instrumen dari penelitian ini menggunakan lembar observasi dan lembar kuesioner. Dalam penelitian ini lembar observasi digunakan untuk mengetahui objek penelitian secara langsung, sehingga peneliti mudah memahami proses pelaksanaan dilapangan. Data yang disajikan nantinya berdasarkan survei lapangan akan dibandingkan dengan teori.
\end{abstract}

Kata Kunci: Rekam medis, rawat inap, tata ruang kantor 


\section{PENDAHULUAN}

Tata Ruang Kantor adalah penyusunan peralatan dan alat perlengkapan kantor pada luas lantai yang tersedia, penentuan mengenai kebutuhan-kebutuhan ruang dan tentang penggunaan secara terperinci dari ruang itu untuk menyiapkan suatu susunan yang yang praktis mengenai peralatan perlengkapan kantor tersebut yang dianggap perlu bagi pelaksanaan kerja kantor dengan biaya yang layak (Diklat Jarak Jauh Sepala 1994:3).

Penataan ruang kerja di unit kerja rekam medis mempengaruhi kegiatan pelayanan, sehingga tata ruang kerja di unit kerja rekam medis perlu diperhatikan agar pelayanan yang diberikan oleh unit kerja rekam medis berjalan lancar (Aris Antoni, M. Mun'im Hendrawi, Ulfah Sukmasari 2014).

Hasil pengukuran luas ruangan rekam medis di RSUD M.Zein Painan didapat luas ruangan pengolahan $3,4 \mathrm{~m} \times 3,8 \mathrm{~m}$ yang ditempati oleh 3 orang petugas rekam medis, 3 meja petugas, 5 kursi, 1 rak berkas dan lemari. Luas ruangan penyimpanan (I) 3,8m x 7,4m yang ditempati oleh 9 petugas rekam medis, 1 meja petugas, 1 rak dan 5 roll o'pack. Dan luas ruangan penyimpanan (II) $1,7 \mathrm{~m} \times 10,6 \mathrm{~m}$ yang ditempati oleh 9 orang petugas dan 5 rak serta adanya berkas yang disusun dilantai. Luas ruangan rekam medis di RSUD M. Zein Painan ini belum memenuhi standar yang ditentukan, akibatnya petugas rekam medis tidak dapat mencari berkas dan mengolah data dengan cepat karena tidak bisa bergerak dengan leluasa (Oktamianiza dan Sinta Andriani 2016).

Aspek tata ruang kantor dalam lingkungan kerja sangat mempengaruhi kualitas dan kinerja bagi organisasi yang bersangkutan. Tata kerja di ruang Perekam Medis dapat disesuaikan dengan alur kerja. Salah satu pendukungnya adalah sarana dan prasarana yang memadai yang akan membantu dalam pelaksanaan kegiatan, sehingga tercipta lingkungan kerja yang cocok, aman, nyaman dan tidak menimbulkan keluhan-keluhan petugas, serta dapat mengurangi kelelahan.

Berdasarkan latar belakang di atas, perlu mendekripsikan tatanan dariruang kerja. Tujuan penelitian iniialah Merancang Ulang Ruang Kerja Bagian Rekam Medis Rawat Inap Berdasarkan Aspek Tata Ruang Kantor.

\section{METODE}

Penelitian ini menggunakan deskriptif yaitu digunakan untuk mengevaluasi ruang kerja bagian rekam medis rawat inap berdasarkan aspek tata ruang kantor. Rancangan penelitian ini adalah kegiatan penelitian dari tahap persiapan, pengumpulan data, pengolahan data atau analisis data, penarikan kesimpulan dan penyusunan laporan penelitian. waktu penelitian dilaksanakan pada bulan AprilAgustus 2019. Sampel yang digunakan untuk penelitian adalah ruang kerja bagian rekam medis rawat inap Rumah Sakit Delta Surya Sidoarjo dengan 3 sampel kuesioner dari Perekam Medis.

Instrumen yang digunakan dalam penelitian ini adalah Lembar Observasi digunakan oleh peneliti untuk mencatat hasil pengamatan yang dilakukan di lapangan. Lembar observasi berisi tentang materimateri sesuai dengan keperluan peneliti, Lembar Kuesioner digunakan oleh peneliti untuk memperoleh jawaban dari perekam medis mengenai hasil rancangan tata letak ruang bagian Perekam Medis Rawat Inap, dan SketchUp Viewer adalah software yang digunakan peneliti untuk membuat rancangan tata letak ruang kerja bagian Perekam Medis.

\section{HASIL PENELITAN}

Berdasarkan hasil observasi pada penelitian di Ruang Kerja Rekam Medis Rawat Inap Rumah Sakit Delta Surya Sidoarjo dapat diperoleh hasil sebagai berikut :

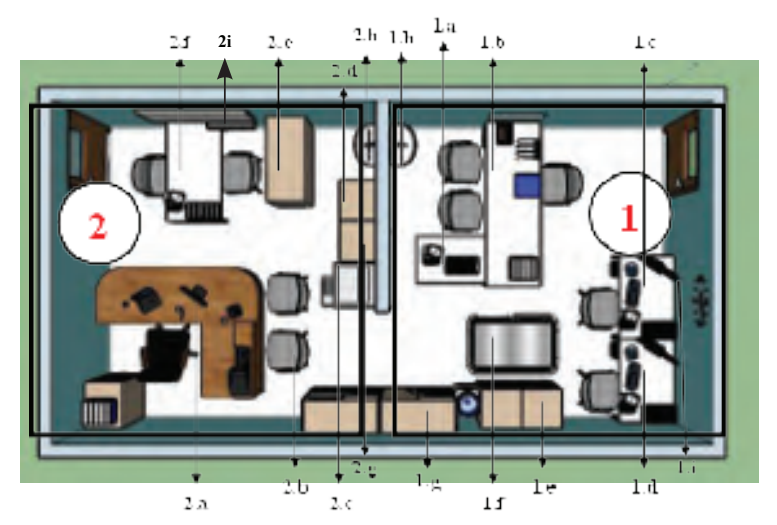

Keterangan :

\begin{tabular}{|c|c|c|c|}
\hline \multicolumn{2}{|c|}{$\begin{array}{l}\text { No. } 1 \text { Ruang kerja bagian Rekam } \\
\text { Medis Rawat Inap Rumah Sakit } \\
\text { Delta Surya Sidoarjo, }\end{array}$} & \multicolumn{2}{|c|}{$\begin{array}{c}\text { No. } 2 \text { Ruang kerja Kepala } \\
\text { Bagian Rekam Medis } \\
\text { Rumah Sakit Delta Surya } \\
\text { Sidoarjo }\end{array}$} \\
\hline 1.a & Meja kerja bagian filing & 2.a & Meja kerja Kepala \\
\hline 1.b & Meja kerja bagian assembling & & Bagian Rekam Medis \\
\hline 1.c & Meja kerja bagian scaning & 2.b & Rak laporan \\
\hline 1.d & Meja kerja bagian coding & 2.c & Mesin fotokopi \\
\hline 1.e & Lemari arsip & 2.d & Lemari arsip \\
\hline 1.f & Trolly berkas & 2.e & Lemari laporan \\
\hline $1 . \mathrm{g}$ & Rak laporan & 2.f & Meja kerja bagian re- \\
\hline 1.h & Wastafel & & tensi/pelaporan \\
\hline \multirow[t]{3}{*}{$1 . \mathrm{i}$} & Jam dinding & 2.g & Jam dinding \\
\hline & & $2 . h$ & Wastafel \\
\hline & & $2 . \mathrm{i}$ & Papan tulis \\
\hline
\end{tabular}


Tata Letak Ruang Kerja Kepala Bagian Rekam Medis Rumah Sakit Delta Surya Sidoarjo

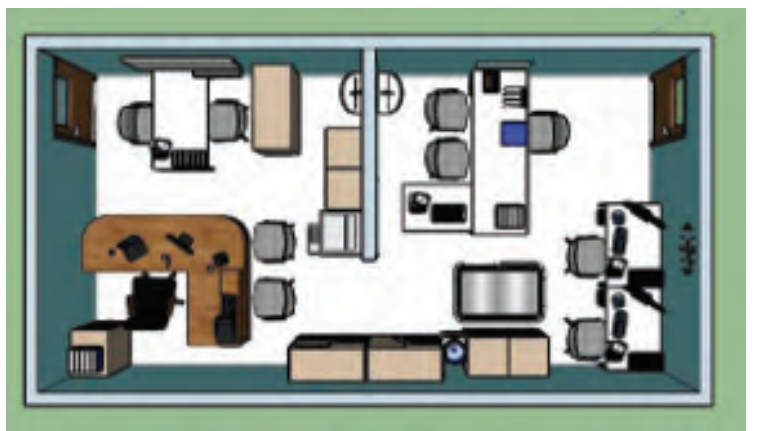

Pada gambar diatas meja kerja Kepala Bagian Rekam Medis dekat dengan pintu keluar dan terletak sejajar dengan meja kerja perekam medis bagian retensi/ pelaporan dengan jarak $1 \mathrm{~m}^{2}$ yang bersebelahan dengan lemari arsip ditambah dua kursi petugas. Meja kerja Kepala bagian Rekam Medis berukuran $360 \mathrm{~cm} \times 75 \mathrm{~cm}$. Terdapat satu kursi untuk Kepala bagian Rekam Medis dan dua kursi untuk tamu di depan meja Kepala bagian Rekam Medis. Ruang kerja Kepala bagian Rekam Medis dekat dengan pintu keluar dan terletak bersebelahan dengan meja kerja Perekam Medis bagian retensi dengan jarak $2,95 \mathrm{~m}^{2}$ yang terletak di samping mesin fotokopi dan sejajar dengan lemari arsip dan lemari laporan.

Tata Letak Ruang Kerja Perekam Medis Rawat Inap Rumah Sakit Delta Surya Sidoarjo.

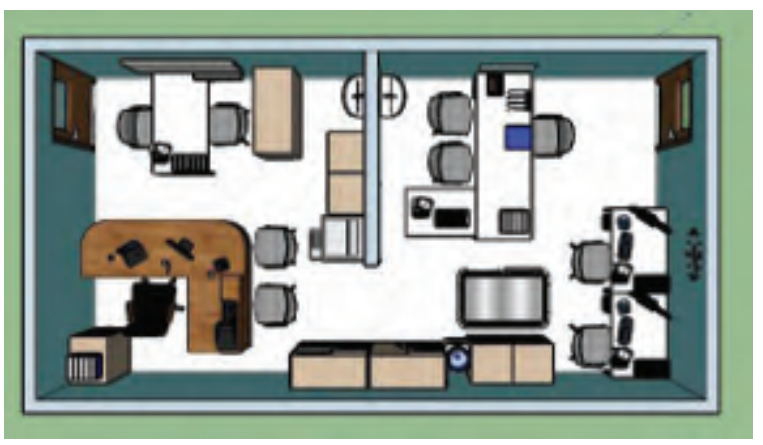

Pada Gambar diatas dapat dilihat bahwa ruang kerja Perekam Medis Rawat Inap Rumah Sakit Delta Surya Sidoarjo terdiri dari meja kerja perekam medis bagian assembling, meja kerja perekam medis bagian coding, meja kerja perekam medis bagian scanning, meja kerja perekam medis bagian dokumen medis, meja kerja perekam medis bagian filing. Ruang kerja bagian Rekam Medis Rawat Inap berukuran 7,8 m2 x 4,2 $\mathrm{m} 2$ yang dibagi dua dengan menggunakan sekat tembok untuk ruang kerja Kepala Bagian Rekam
Medis dan ruang kerja Perekam Medis Rawat Inap. Untuk membawa berkas rekam medis rawat inap ke ruang filing dengan menggunakan trolly besar.

Hasil Kuesioner Tentang Rancangan Ulang Tata Letak Ruang Kerja Bagian Rekam Medis Rawat Inap.

Tabel 1. Hasil Kuesioner Tentang Persetujuan Rancangan Ulang Tata Letak Ruang Kerja

\begin{tabular}{|c|c|c|c|c|c|c|}
\hline \multirow{2}{*}{ No } & \multirow{2}{*}{ Pernyataan } & \multicolumn{3}{|c|}{ Responden } & \multirow{2}{*}{$\begin{array}{c}\text { Jum- } \\
\text { lah }\end{array}$} & \multirow{2}{*}{$\begin{array}{l}\text { To- } \\
\text { tal }\end{array}$} \\
\hline & & 1 & 2 & 3 & & \\
\hline 1. & $\begin{array}{l}\text { Setuju dengan rancangan ulang } \\
\text { ruang kerja bagian Rekam Me- } \\
\text { dis rawat inap yang baru. }\end{array}$ & 3 & 3 & 3 & 9 & \\
\hline 2. & $\begin{array}{l}\text { Apakah setuju dengan denah } \\
\text { (layout) bagian rekam medis } \\
\text { rawat inap sesuai dengan kriteria }\end{array}$ & 3 & 3 & 3 & 9 & \\
\hline 3. & $\begin{array}{l}\text { Apakah rancang ulang yang tel- } \\
\text { ah dibuat dapat mempermudah } \\
\text { alur kinerja bagian rekam medis }\end{array}$ & 4 & 2 & 3 & 9 & \\
\hline 4. & $\begin{array}{l}\text { Apakah rancang ulang yang } \\
\text { telah dibuat dapat diterapkan di } \\
\text { ruang kerja bagian rekam medis }\end{array}$ & 3 & 2 & 3 & 8 & \\
\hline
\end{tabular}

Keterangan:

$1=$ Tidak Setuju

$2=$ Cukup Setuju

$3=$ Setuju

$4=$ Sangat Setuju

\section{PEMBAHASAN}

Tata Letak Ruang Kerja Kepala Bagian Rekam Medis Rumah Sakit Delta Surya Sidoarjo.

Menurut Diklat Jarak Jauh Sepala (1994:11) dalam mengatur tata letak tempat duduk dan peralatan dalam ruangan, kantor pimpinan diletakan di bagian belakang para pegawai. Ruang kerja Kepala Bagian Rekam Medis di Rumah Sakit Delta Surya Sidoarjo terletak dekat dengan pintu akses keluar masuk sejajar dengan meja kerja untuk bagian retensi.

Ruang kerja bagian Rekam Medis rawat inap telah memenuhi standar yang ada, yaitu dekat dengan unit pendaftaran, kasir, instalasi rawat jalan, rawat inap dan gawat darurat.Tata letak ruang kerja Kepala Bagian Rekam Medis di Rumah Sakit Delta Surya Sidoarjo adalah sebagai berikut :

1. Meja Kepala Bagian Rekam Medis terletak di bagian belakang berhadapan dengan meja kerja untuk bagian retensi. 
2. Dengan rancangan yang baru ini letak meja kerja untuk bagian retensi akan diletakkan di belakang mesin fotokopi dan lemari arsip akan diletakkan di depan lemari rak dan meja Kepala Bagian Rekam Medis, sehingga meja kerja bagian retensi akan lebih dekat dengan meja perekam medis lainnya dan waktu kerja perekam medis lebih efisien.

\section{Tata Letak Ruang Kerja Perekam Medis Rawat Inap Rumah Sakit Delta Surya Sidoarjo}

Ruang kerja bagian rekam medis rawat inap di Rumah Sakit Delta Surya Sidoarjo memiliki luas ruangan dengan ukuran 7,8 $\mathrm{m}^{2}$ x 4,2 $\mathrm{m}^{2}$ yang diberi sekat tembok untuk ruangan Kepala Bagian Rekam Medis dan Perekam medis lainnya. Ruang penyimpanan berkas rekam medis rawat inap terdapat di lantai dua yang memiliki satu pintu untuk akses keluar masuk dan ruangan selalu terkunci. Ruang kerja bagian Perekam Medis rawat inap tidak diubah karena tata letak meja kerja sudah sesuai dengan alur kerja Perekam Medis.

\section{Hasil Kuesioner Tentang Rancangan Ulang Tata Letak Ruang Kerja Bagian Rekam Medis Rawat Inap}

Perhitungan skor dari hasil kuesioner dari 3 (tiga) orang Perekam Medis Rawat Inap dengan 4 pertanyaan didapatkan total seluruh pernyataan sebesar 35 dengan hasil skor akhir adalah 2,92 dengan kriteria skor adalah setuju. Ini berarti hasil rancangan ulang ruang kerja Perekam Medis Rumah Sakit Delta Surya Sidoarjo dapat dipergunakan.

Tabel 2. Hasil Kuesioner Tentang Persetujuan Rancangan Ulang Tata Letak Ruang Kerja Dengan Nilai Skor Akhir

\begin{tabular}{llll}
\hline & Pernyataan & $\begin{array}{c}\text { Res- } \\
\text { ponden }\end{array}$ Jumlah & Total Skor \\
\cline { 2 - 3 } & \begin{tabular}{lll} 
Akhir \\
\hline
\end{tabular} & 2 & 3 \\
\hline
\end{tabular}

\section{Setuju dengan rancangan}

1. ulang ruang kerja bagian $\begin{array}{lllll}3 & 3 & 3 & 9\end{array}$

Rekam Medis rawat inap

yang baru.

Apakah setuju dengan

$\begin{array}{llllllll}\text { 2. } \begin{array}{lllll}\text { denah (layout) bagian } \\ \text { rekam medis rawat inap }\end{array} & 3 & 3 & 3 & 9 & 35 & 2,92\end{array}$ sesuai dengan kriteria

Apakah rancang ulang

3. yang telah dibuat dapat $\begin{array}{lllll}4 & 2 & 3 & 9\end{array}$

mempermudah alur kinerja bagian rekam medis
Apakah rancang ulang

$\begin{array}{llllll}\text { 4. } \begin{array}{llll}\text { yang telah dibuat dapat } \\ \text { diterapkan di ruang kerja }\end{array} & 3 & 2 & 3 & 8\end{array}$

bagian rekam medis

\section{Rancangan Ulang Ruang Kerja Kepala Bagian Rekam Medis Rumah Sakit Delta Surya Sidoarjo.}
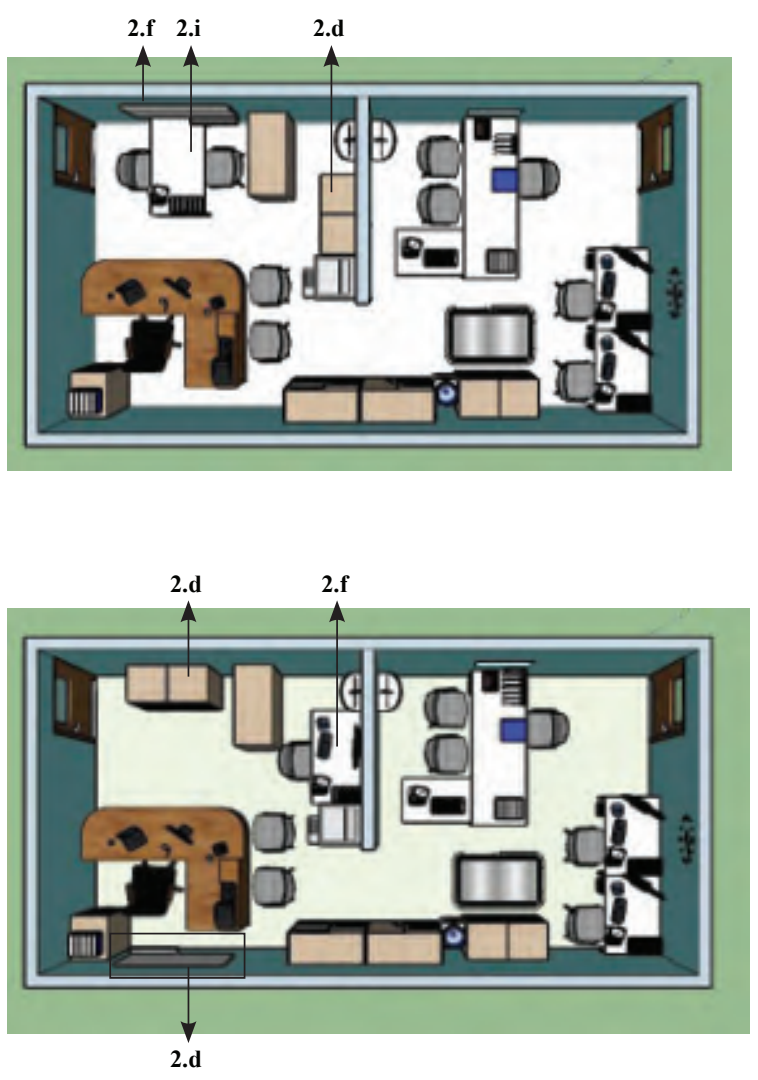

Keterangan:

No. 2 Ruang kerja Kepala Bagian Rekam Medis Rumah Sakit Delta Surya Sidoarjo

2.d Lemari arsip

2.f Meja kerja bagian retensi/pelaporan

2.i Papan tulis

Berdasarkan gambar diatas, meja kerja bagian retensi (A. Desain lama) terlalu jauh dengan meja perekam medis lainnya sehingga sesuai dengan permintaan Kepala bagian Rekam Medis dilakukan perancangan ulang agar terciptanya kenyamanan kerja bagi perekam medis dalam melakukan pekerjaannya. Dapat dilihat bahwa sudah mampu memenuhi standar tata ruang yang baik dengan pemisah ruangan antara ruang kerja Kepala bagian Rekam Medis dan Perekam Medis. Rancangan di atas dilakukan pemindahan meja kerja perekam 
medis bagian retensi (B. Desain baru) diletakkan di samping mesin fotokopi dan pemindahan papan tulis (B. Desain baru) di samping meja Kepala Bagian Rekam Medis. Peneliti mengusulkan perancangan ini untuk memudahkan tugas Perekam Medis.

Rancangan tata letak ruang kerja bagian Rekam Medis Rawat Inap Rumah Sakit Delta Surya Sidoarjo sudah memenuhi keempat Aspek Tata Ruang Kantor, yaitu:

1. Azaz Jarak Terpendek

Mulai dari kegiatan assembling hingga kegiatan pelaporan.

2. Azaz Rangkaian Kerja

Mulai dari Perekam Medis yang melakukan pekerjaan assembling hingga pekerjaan pelaporan sudah ditempatkan sesuai rangkaian urutan kerja dan menempati meja sesuai pekerjaannya.

3. Azaz Penggunaan Segenap Ruang

Ruangan ini memanfaatkan seluruh fasilitas yang ada, sehingga seluruh fasilitas digunakan tidak ada yang sia-sia.

4. Azaz Perubahan Susunan Tempat Kerja

Penempatan meja dan kursi serta peralatan lainnya posisi dapat diubah atau disusun kembali dengan mudah.

Alur kerja di ruang Perekam Medis rawat inap sudah disesuaikan dengan pekerjaan masingmasing sehingga memudahkan Perekam Medis dalam melakukan pekerjaan. Berdasarkan Tabel 2 dari 3 responden (bagian rekam medis) dengan 4 pertanyaan didapatkan total seluruh pernyataan sebesar 35 dengan hasil skor akhir adalah 2,92 sesuai dengan kriteria skor adalah setuju. Dengan demikian ini bisa dikatakan hasil rancangan ulang ruang kerja Rekam Medis Rawat Inap Rumah Sakit Delta Surya Sidoarjo dapat dipergunakan.

\section{SIMPULAN}

Tujuan pertama tentang identifikasi tata letak ruang kerja Kepala bagian Rekam Medis hasil kesimpulan yang dapat ditarik yaitu kepala bagian rekam medis sering menerima tamu sehingga ruangan harus lebih privasi, tidak menjadi satu dengan ruang kerja Perekam Medis dan terletak dekat dengan urusan pelaporan, tujuan yang kedua yaitu identifikasi tata letak ruang kerja bagian rekam medis rawat inap dimana ruang kerja bagian rekam medis Rawat Inap tidak dekat dengan ruang penyimpanan yang terletak di lantai dua sehingga membuat kerja perekam medis rawat inap kurang efisien, dan tujuan yang terakhir yaitu rancangan ulang tata letak ruang kerja bagian rekam medis rawat inap dimana letak meja kepala bagian rekam medis sebelumnya berhadapan dengan meja kerja untuk bagian retensi, pada rancangan tata letak yang baru meja kerja untuk bagian retensi bersebelahan dengan mesin fotokopi dan meja kepala bagian rekam medis berhadapan dengan lemari arsip dan lemari laporan.

\section{UCAPAN TERIMA KASIH}

Ucapan terima kasih kami sampaikan kepada STIKES Yayasan Rumah Sakit Dr.Soetomo Surabaya, temanteman, dan khususnya untuk keluarga atas bimbingan dan dukungan kepada peneliti.

\section{DAFTAR PUSTAKA}

Antoni, Aris, M. Mun'im Hendrawi dan Ulfah Sukmasari. 2014. Tinjauan Tata Letak Ruang Guna Kelancaran Proses Pelayanan Rekam Medis di UKRM BLUD RSU Banjarbaru Tahun 2014. Jurkessia. Volume 5 (2).

Depkes RI. 2006. Pedoman Penyelenggara dan Prosedur Rekam Medis Rumah Sakit Indonesia. Direktorat Jendral Bina Pelayanan Medik. Jakarta.

Hospital, T. G. (n.d.). Kesehatan dan Kualitas Kehidupan Kerja terhadap Kinerja Perawat di Rumah Sakit Umum Tangerang Tangerang General Hospital, 59-66.

Kementerian Kesehatan. (2013). Peraturan Menteri Kesehatan Republik Indonesia Nomor 55 Tahun 2013 Tentang Penyelenggaraan Pekerjaan Perekam Medis. Jakarta: Kementerian Kesehatan.

Majid, C. A. (2018). Desain Ulang Ruang Penyimpanan Dokumen Rekam Medik Aktif Di Rumah Sakit Mata Masyarakat Jawa Timur Berdasarkan Ilmu Ergonomi. Surabaya.

Media, O. (2017). Pengertian, Jenis, Asas Dan Tujuan Tata Ruang Kantor. Retrieved from odemedia.blogspot.com/2017/11/pengertianjenis-asas-dan-tujuan-tata.html?m=1. 7 mei 2019(15:18) 
Nopianto, H., Riyanto, B., \& Ariani, M. D. (2012). Faktor-Faktor yang Berpengaruh terhadap Lama Rawat Inap pada Pasien Demam Berdarah Dengue di RSUP DR Kariadi Semarang. Fakultas Kedokteran.

Oktamianiza, Sinta Andriani. 2016. Tinjauan Kondisi Fisik Ruangan Terhadap Kinerja Petugas Dalam Pengolahan Rekam Medis Di Rsud M. Zein Painan. Jurnal Manajemen Informasi Kesehatan Indonesia. Volume 4 (83).

Peraturan Menteri Kesehatan Republik Indonesia Nomor 72 Tahun 2016. (2016).

Rumah, D. I., \& Paru, S. (2017). urusan pelaporan, urusan kepala rekam medis, perekam medis, tata letak ruang unit rekam medis, tata letak ruang urusan, 3(1).

Sepala, D. J. J. (1994). Teknik Menata Ruang Kantor. Jakarta: Lembaga Administrasi Negara Republlik Indonesia.

Sosial, D., \& Dan, T. K. (2010). Pengaturan tata ruang kantorpada dinas sosial, tenaga kerja dan transmigrasi kabupaten kudus.

Undang-undang Republik Indonesia Nomor 44 Tahun 2009 Tentang Rumah Sakit 2009. Lembaran Negara Republik Indonesia Tahun 2009 Nomor 40. Jakarta. 